\title{
EFEK KUERSETIN TERHADAP KADAR GLUKOSA DARAH PUASA PADA TIKUS DIABETES MELITUS TIPE 2 YANG DIINDUKSI DENGAN STREPTOZOTOCIN-NICOTINAMIDE
}

\author{
Fitriani, N.E, ${ }^{1}$ Akhmad, S.A ${ }^{2}$ Lestariana, W. ${ }^{2}$ \\ ${ }^{1}$ Mahasiswa FakultasKedokteranUniversitas Islam Indonesia \\ ${ }^{2}$ Departemen BiokimiaFakultasKedokteranUniversitas Islam Indonesia
}

\begin{abstract}
ABSTRAK
Latar belakang

Diabetes melitus (DM) tipe 2 adalah penyakit kronis yang dapat menyebabkan berbagai komplikasi. Pengobatan DM yang lebih efektif dan aman sampai saat ini masih terus dikembangkan. Salah satunya adalah terapi menggunakan antioksidan kuersetin. Beberapa penelitian sebelumnya menunjukan bahwa kuersetin memiliki beberapa efek antidiabetik termasuk dapat menurunkan kadar gula darah.
\end{abstract}

\section{Tujuan penelitian}

Mengetahui efek pemberian kuersetin terhadap kadar glukosa darah puasa pada tikus diabetes melitus tipe 2 yang diinduksi dengan streptozotocin dan nicotinamide.

\section{Metode}

Penelitian ini menggunakan sampel 16 ekor tikus. Subjek dibagi menjadi 4 kelompok. Kelompok 1 diberi plasebo, kelompok 2 diberi glibenklamid $5 \mathrm{mg} / \mathrm{kgbb}$, kelompok 3 diberi kuersetin $20 \mathrm{mg} / \mathrm{kgbb}$ dan kelompok 4 diberi kombinasi glibenklamid $5 \mathrm{mg} / \mathrm{kgbb}$ dan kuersetin $20 \mathrm{mg} / \mathrm{kgbb}$. Perlakuan selama 4 minggu. Kadar glukosa darah puasa diukur dengan spektofotometri.

\section{Hasil}

Hasil penelitian menunjukan bahwa terdapat perbedaan yang bermakna pada kadar glukosa darah puasa sebelum dan sesudah perlakuan pada kelompok yang diberi kombinasi glibenklamid $5 \mathrm{mg} / \mathrm{kgbb}$ dengan kuersetin $20 \mathrm{mg} / \mathrm{kgbb}(\mathrm{p}=0.015)$. Sedangkan, kelompok yang diberi plasebo, glibenklamid $5 \mathrm{mg} / \mathrm{kgbb}$ dan kuersetin $20 \mathrm{mg} / \mathrm{kgbb}$ tidak menunjukan perbedaan yang bermakna $(\mathrm{p}=0.148),(\mathrm{p}=0.533)$ dan $(\mathrm{p}=0.152)$. Tidak terdapat perbedaan bermakna kadar gula darah puasa setelah perlakuan antara kelompok yang diberi plasebo, glibenklamid, kuersetin maupun kombinasi keduanya.

\section{Kesimpulan}

Terdapat perbedaan yang bermakna secara statistik pada kadar glukosa darah puasa sebelum dan sesudah perlakuan pada kelompok yang diberi kombinasi glibenklamid dengan kuersetin.

Kata kunci : Diabetes melitus tipe 2, kuersetin, glibenklamid, kadar glukosa darah puasa. 


\section{ABSTRACT}

\section{Background}

Type 2 diabetes mellitus (T2DM) is a chronic disease leading to various complications. More effective and safer treatment of diabetes mellitus is still sought. One of therapeutic agent that used was quercetin. Previous studies showed that quercetin had antidiabetic effects, one of them is reducing blood glucose.

\section{Objective}

The aim of this research were determine the effect of quercetin on fasting blood glucose levels in rats with type 2 diabetes mellitus induced by streptozotocin and nicotinamide.

\section{Method}

This study was an experimental study design with a total samples of 16 rats. Subjects were divided into 4 groups. Each group was given with placebo, $5 \mathrm{mg} / \mathrm{kg}$ of body weight glibenclamide, 20 $\mathrm{mg} / \mathrm{kg}$ of body weight quercetin, or combination of glibenclamide and quercetin, respectively. Treatment given for 4 weeks. Fasting blood glucose levels were measured using spectophotometric.

\section{Result}

The results showed that there were significant differences in fasting glucose levels before and after treatment in group given combination of glibenclamide $5 \mathrm{mg} / \mathrm{kg}$ of body weight with quercetin 20 $\mathrm{mg} / \mathrm{kg}$ of body weight $(\mathrm{p}=0,015)$. While group given placebo, glibenclamide and $20 \mathrm{mg} / \mathrm{kg}$ of body weight quercetin did not show any significant difference $(p=0.148),(p=0.533)$ and $(p=0.152)$. There was no significant difference of fasting blood glucose within group.

\section{Conclusion}

There were statistically significant differences in fasting glucose levels before and after treatment in groups given combination glibenclamide with quercetin

Keywords : Diabetes mellitus type 2, Quercetin, glibenclamide, Fasting blood glucose levels.

\section{PENDAHULUAN}

Diabetes atau yang sering disebut sebagai penyakit kencing manis adalah penyakit metabolik tersering dan insidennya terus meningkat. ${ }^{1}$ Meningkatnya angka kejadian diabetes melitus (DM) di beberapa negara berkembang terjadi akibat adanya peningkatan taraf hidup di negara tersebut. ${ }^{2}$ Menurut WHO, diabetes melitus disebabkan oleh keturunan dan atau didapat karena defisiensi insulin yang diproduksi oleh pankreas, atau karena produksi insulin yang tidak efektif. Diabetes melitus tipe 2 meliputi $90 \%$ dari semua populasi diabetes dan faktor lingkungan memiliki peran dalam terjadinya DM. ${ }^{2}$ Terdapat peningkatan epidemi diabetes tipe 2 pada anak muda sesuai dengan peningkatan

(DM) adalah penyakit kronis yang 
obesitas dan gaya hidup yang kurang sehat pada kelompok usia ini. ${ }^{3}$

Perkiraan WHO bahwa pada tahun 2000 jumlah penderita diabetes diatas umur 20 tahun berjumlah 150 juta orang dan dalam kurun waktu 25 tahun kemudian (2025) jumlah itu akan naik menjadi 300 juta orang. Dengan perkiraan yang telah dibuat oleh WHO, maka Indonesia akan menempati peringkat nomor 5 sedunia dengan jumlah pengidap diabetes sebanyak 12,4 juta orang pada tahun 2025, naik 2 tingkat dibanding tahun $1995 .^{4}$

Saat ini ada beberapa obat yang dapat digunakan untuk mengobati diabetes. Namun, banyak dari obat-obatan antidiabetik memiliki efek samping. Oleh karena itu pengelolaan diabetes tanpa efek samping masih merupakan sebuah tantangan bagi para peneliti untuk mencari obat baru yang lebih efektif dan aman untuk pengobatan diabetes. ${ }^{5}$

Indonesia adalah negara dengan kekayaan sumber daya alam yang sangat melimpah. Kekayaan sumber daya alam itu termasuk di dalamnya adalah tanamantanaman: daun, bunga, buah atau akarnya dapat dijadikan obat untuk mengobati atau mencegah berbagai penyakit. Begitu pula dengan diabetes melitus, orang-orang menggunakan bahan-bahan alami untuk menurunkan kadar gula darah yang tinggi. Peningkatan kadar gula darah (hiperglikemia) merupakan tanda utama pada penyakit DM. Salah satu zat yang berperan dalam menurunkan gula darah yang terdapat dalam tanaman adalah kuersetin

Kuersetin adalah flavonoid utama yang termasuk pada kelas flavonol. Tidak banyak orang yang tahu bahwa kuersetin banyak ditemukan pada makanan yang dikonsumsi sehari-hari. Pada umumnya kuersetin banyak ditemukan pada makanan seperti apel, teh, bawang, kacang, buah, kembang kol, kubis dan makanan lainnya. ${ }^{6}$ Beberapa penelitian menunjukkan bahwa kuersetin memliki efek sebagai antioksidan, antiproliferatif, antiinflamasi, antikarsinogenik, antihipertensi, antidiabetik dan mampu melindungi terhadap berbagai jenis penyakit seperti osteoporosis, bentukbentuk tertentu dari kanker, penyakit paruparu dan jantung, juga terhadap penuaan. Berdasarkan latar belakang tersebut, peneliti tertarik untuk meneliti mengenai efek pemberian kuersetin terhadap kadar gula pada tikus diabetes melitus tipe 2 yang diinduksi dengan streptozotocin (STZ) dan nikotinamid. 


\section{METODE PENELITIAN}

Penelitian ini merupakan penelitian eksperimental murni untuk melihat efek pemberian kuersetin terhadap kadar glukosa darah puasa pada tikus diabetes melitus tipe 2. Subjek penelitian ini adalah tikus jantan galur Wistar berusia 12-16 minggu dengan berat 200-300 gram. Jumlah sampel yang digunakan sebanyak 16 ekor tikus yang dibagi menjadi empat kelompok. Kelompok pertama (K1) adalah kelompok yang mendapat plasebo, kelompok kedua (K2) mendapat glibenklamid $5 \mathrm{mg} / \mathrm{kgbb}$, kelompok ketiga (K3) mendapat kuersetin $20 \mathrm{mg} / \mathrm{kgbb}$ dan kelompok keempat (K4) mendapat kombinasi glibenklamid 5 $\mathrm{mg} / \mathrm{kgg}$ dan kuersetin $20 \mathrm{mg} / \mathrm{kgbb}$.

Perlakuan diberikan selama 4 minggu. Bahan uji adalah kuersetin dalam bentuk serbuk berisi kuersetin aglikon (kuersetin aktif) dari Sigma®. Hewan coba diperoleh dari Laboratorium Pusat Antar Universitas (PAU) Universitas Gadjah Mada. Tikus Wistar jantan berjumlah 16 ekor yang berusia 12-16 minggu dengan berat badan 200-300 gram. Sebelum diberi perlakuan semua tikus diadaptasi selama satu minggu. Satu minggu setelah diadaptasi tikus akan diinduksi menggunakan Streptozotocin $60 \mathrm{mg} / \mathrm{kgBB}$ dan Nicotinamide $120 \mathrm{mg} / \mathrm{kgBB}$ secara intraperitoneal agar terjadi diabetes melitus tipe 2. Setelah 1-3 minggu paska induksi, tikus dengan kadar gula darah puasa $>126$ $\mathrm{mg} / \mathrm{dL}$ dinyatakan mengalami diabetes melitus. Kemudian tikus dibagi menjadi 4 kelompok yang masing-masing kelompok terdiri dari 4 ekor tikus. Kelompok pertama (K1) adalah kelompok yang mendapat plasebo, kelompok kedua (K2) mendapat glibenklamid $5 \mathrm{mg} / \mathrm{kgbb}$, kelompok ketiga (K3) mendapat kuersetin $20 \mathrm{mg} / \mathrm{kgbb}$ dan kelompok keempat (K4) mendapat kombinasi glibenklamid $5 \mathrm{mg} / \mathrm{kgg}$ dan kuersetin $20 \mathrm{mg} / \mathrm{kgbb}$. Perlakuan diberikan selama empat minggu dan di akhir penelitian kadar glukosa darah puasa tikus akan diukur dengan metode GOD-PAP menggunakan spektofotometri. Untuk mengetahui perbedaan kadar glukosa darah hewan coba sebelum dan sesudah perlakuan pada masing-masing kelompok digunakan analisis uji Paired T-Test dan untuk mengetahui perbedaan kadar glukosa darah puasa sesudah perlakuan antar kelompok digunakan analisis uji One Way Annova dilanjutkan dengan uji post hoc. 


\section{HASIL PENELITIAN}

\section{Karakteristik Hasil Penelitian}

Subjek penelitian ini adalah tikus jantan galur Wistar berusia 12-16 minggu dengan berat 200-300 gram. Jumlah sampel yang digunakan sebanyak 16 ekor tikus yang dibagi rata-rata kadar glukosa darah sebelum perlakuan lebih tinggi daripada rata-rata kadar glukosa darah setelah perlakuan pada masing-masing kelompok kecuali pada kelompok 1 yaitu kelompok yang mendapatkan plasebo. Berdasarkan

Tabel 1. Kadar Glukosa Darah puasa (mg/dL) Sebelum dan Sesudah Perlakuan

\begin{tabular}{|c|c|c|c|c|c|c|c|c|}
\hline \multirow{3}{*}{$\begin{array}{l}\text { Tikus } \\
\text { Peneli } \\
\text {-tian }\end{array}$} & \multicolumn{8}{|c|}{ Kelompok } \\
\hline & \multicolumn{2}{|c|}{1} & \multicolumn{2}{|c|}{2} & \multicolumn{2}{|c|}{3} & \multicolumn{2}{|c|}{4} \\
\hline & pre & post & pre & post & pre & post & pre & post \\
\hline 1 & 181,51 & 491,69 & 277,09 & 47,5 & 384,1 & 331,28 & 155,66 & 71,7 \\
\hline 2 & 155,9 & 330,78 & 220,21 & 54,36 & 145,85 & 146,67 & 381,73 & 184,18 \\
\hline 3 & 138,4 & 146,79 & 182,2 & 322,41 & 127,81 & 140 & 311,14 & 98,47 \\
\hline 4 & 176,71 & 217,57 & 129,5 & 147,78 & 180,09 & 101,27 & 188,89 & 67,52 \\
\hline Rata-rata & 163,13 & 296,7 & 224,2 & 143,08 & 209,46 & 179,8 & 259,35 & 105,46 \\
\hline
\end{tabular}

menjadi empat kelompok. Kelompok pertama (K1) adalah kelompok yang mendapat plasebo, kelompok kedua (K2) mendapat glibenklamid 5 mg/kgbb, kelompok ketiga (K3) mendapat kuersetin $20 \mathrm{mg} / \mathrm{kgbb}$ dan kelompok keempat (K4) mendapat kombinasi glibenklamid $5 \mathrm{mg} / \mathrm{kgg}$ dan kuersetin $20 \mathrm{mg} / \mathrm{kgbb}$. Karakteristik subjek penelitian berdasarkan kadar glukosa darah puasa sebelum dan setelah perlakuan disajikan dalam Tabel 1.

Berdasarkan Tabel 1, didapatkan hasil pemeriksaan kadar glukosa darah puasa tikus yang menunjukan bahwa
Tabel 1 dapat diketahui bahwa rata-rata terjadi kenaikan kadar glukosa darah puasa pada kelompok plasebo sebesar 133,6 mg/dL (83,1\%) sedangkan pada kelompok 2, 3, dan 4 rata-rata terjadi penurunan sebesar 81,2 mg/dL (36,2\%); $29,6 \mathrm{mg} / \mathrm{dL}(14,1 \%)$ dan $153,89 \mathrm{mg} / \mathrm{dL}$ $(59,3 \%)$.

\section{Analisis Perbedaan Kadar Glukosa Darah Sebelum dan Sesudah Perlakuan}

Perbedaan kadar gula darah puasa sebelum dan setelah perlakuan masingmasing kelompok diuji dengan Paired $T$ Test yang tersaji dalam Tabel 2.

Berdasarkan hasil uji Paired T-Test pada Tabel 2, diperoleh hasil hanya 
kelompok yang mendapat perlakuan insulin. Glibenklamid termasuk dalam kombinasi glibenklamid dengan kuersetin golongan sulfonilurea generasi kedua yang (K4) yang menunjukan perbedaan secara luas digunakan baik sebagai mono bermakna kadar glukosa darah puasa terapi ataupun kombinasi karena sebelum dan sesudah perlakuan $(\mathrm{p}<0,05)$. kemampuannya dalam mengontrol glukosa Kelompok yang mendapat plasebo, darah secara efisien. ${ }^{8}$ Selain itu sulfonilurea

Tabel 2. Hasil uji perbedaan kadar gula darah puasa sebelum dan sesudah perlakuan dengan Paired T-Test.

\begin{tabular}{cc}
\hline Kelompok perlakuan & Nilai p \\
\hline K1 & 0,148 \\
\hline K2 & 0,533 \\
\hline K3 & 0,265 \\
\hline K4 & 0,015 \\
\hline
\end{tabular}

Ket. K1 adalah kelompok yang mendapat plasebo, K2 mendapat glibenklamid $5 \mathrm{mg} / \mathrm{kgbb}, \mathrm{K} 3$ mendapat kuersetin $20 \mathrm{mg} / \mathrm{kgbb}$ dan $\mathrm{K} 4$ mendapat kombinasi glibenklamid $5 \mathrm{mg} / \mathrm{kgg}$ dan kuersetin $20 \mathrm{mg} / \mathrm{kgbb}$.

glibenklamid dan kuersetin tidak berbeda bermakna $(\mathrm{p}>0,05)$.

\section{Analisis Kadar Glukosa Darah}

\section{Puasa Setelah Perlakuan}

Pada uji One Way Annova didapatkan nilai $\mathrm{p}>0,156$, artinya tidak terdapat perbedaan yang bermakna pada kadar glukosa darah puasa sesudah perlakuan antara kelompok yang mendapat plasebo, glibenklamid, kuersetin dan kombinasi glibenklamid dengan kuersetin.

\section{PEMBAHASAN}

Glibenklamid merupakan obat standar untuk pengobatan diabetes melitus tipe 2. Obat ini termasuk dalam golongan sulfonilurea yang merupakan sekretagok sering diberikan sebagai terapi kombinasi karena memiliki kemampuan untuk meningkatkan atau mempertahankan sekresi insulin. Mekanisme kerja golongan obat ini adalah untuk merangsang sel beta pankreas untuk melepaskan insulin. ${ }^{9}$ Kombinasi antara glibenklamid dengan kuersetin memberikan perbedaan yang bermakna pada kadar glukosa darah puasa sebelum dan sesudah perlakuan kemungkinan disebabkan oleh mekanisme kerja yang berbeda dari glibenklamid dan kuersetin. Glibenklamid yang merupakan golongan sulfonilurea akan meningkatkan atau mempertahankan sekresi insulin sedangkan kuersetin akan memperlambat absorbsi glukosa sehingga efek 
hipoglikemik akan meningkat. Karena bermakna pada penurunan kadar glukosa glibenklamid merupakan substrat dari isoenzim CYP3A4, sehingga pemberian kuersetin yang merupakan inhibitor CYP3A4 pada pasien diabetes melitus yang menerima glibenklamid dapat membantu dalam pengurangan dosis sehingga efek samping dapat diminimalkan. ${ }^{8}$

Pada hasil uji perbedaan kadar gula darah puasa sebelum dan sesudah perlakuan kelompok yang diberi glibenklamid 5 $\mathrm{mg} / \mathrm{kgbb}$ yang tidak bermakna secara statistik kemungkinan disebabkan oleh faktor kondidi hewan coba. Hewan coba memperoleh perlakuan setelah memenuhi kriteria DM yaitu kadar gula darah puasa > $126 \mathrm{mg} / \mathrm{dL}$. Pada penelitian ini terjadi variasi waktu tikus memenuhi kriteria DM. Kemungkinannya tikus pada kelompok yang menerima glibenklamid saja mendapat perlakuan setelah 3 minggu paska induksi sehingga telah terjadi kerusakan pankreas yang lebih berat dan kurang berefek ketika diterapi dengan glibenklamid.

Pemberian kuersetin pada dosis 15 $\mathrm{mg} / \mathrm{kgbb}$ secara intraperitoneal dapat mencegah terjadinya hiperglikemia dan menormalkan kembali kadar glukosa darah pada tikus yang diinduksi diabetes melitus. ${ }^{10}$ Beberapa penelitian sebelumnya dosis minimal yang menimbulkan efek darah adalah $50 \mathrm{mg} / \mathrm{kgbb}$. Dalam penelitian tersebut juga terbukti bahwa kuersetin dapat mengontrol kadar glukosa darah puasa dan hiperglikemia postprandial. Mekanisme utama penurunan kadar glukosa darah diperantai oleh aktivitas inhibisi pada enzim alfa-glukosidase, sehingga absorbsi dari glukosa dapat diperlambat. Berbeda dengan acarbose yang mekanisme kerjanya juga menghambat kerja enzim alfa-amilase dengan kuat, sehingga menimbulkan efek samping pada gastrointenstinal seperti rasa tidak nyaman di perut, flatulen dan diare. ${ }^{11}$ 12 Pada penelitian ini yang digunakan adalah dosis $20 \quad \mathrm{mg} / \mathrm{kgbb}$. Jika dibandingkan dengan penelitian sebelumnya maka dosis yang digunakan dalam penelitian ini lebih rendah. Pada peneltian sebelumnya pemberian kuersetin dilakukan secara intraperitoneal sedangkan pada penelitian ini pemberian kuersetin dilakukan secara oral sehingga kemungkinan memberikan efek yang berbeda karena tingkat absorbsi yang berbeda pula. Kemungkinan pemberian dosis yang lebih rendah dan cara pemberian yang berbeda yang menyebabkan perubahan pada kadar glukosa darah puasa sebelum dan sesudah perlakuan menjadi 
tidak bermakna pada pemberian kuersetin $20 \mathrm{mg} / \mathrm{kgbb}$.

Pada penelitian ini terdapat beberapa keterbatasan diantaranya adalah jumlah subjek penelitian yang terbatas, perbedaan waktu tikus memenuhi kriteria DM serta pengecekan kadar glukosa darah dilakukan secara mandiri di laboratorium sehingga memungkinkan terjadinya kesalahan.

\section{KESIMPULAN}

Berdasarkan hasil penelitian dapat diambil kesimpulan yaitu terdapat perbedaan yang bermakna kadar gula darah puas atikus DM tipe 2 sebelum dan setelah perlakuan pada kelompok yang mendapatkan kombinasi glibenklamid dengan kuersetin.

\section{DAFTAR PUSTAKA}

1. Beckett GJ. Lecture Note Clinical Biochemistry $\left(8^{\text {th }}\right.$ Ed.). Oxford: WileyBlackwell; 2010.

2. Soegondo S. Diagnosis dan Klasifikasi Diabetes Melitus Terkini. Dalam : Soegondo S, dkk, editor, Penatalaksanaan Diabetes Melitus Terpadu, Edisi 2. Jakarta: Penerbit FK UI; 2007.

3. Brashers VL. Aplikasi Klinis Patofisiologi : pemeriksaan \& manajemen ( $2^{\text {nd }} E d$.). Kuncoro (AlihBahasa), Edisi 2. Jakarta: Penerbit Buku Kedokteran EGC; 2007.

4. Suyono S. Diabetes Melitus Di Indonesia. Dalam : Sudoyo A. W., dkk, editor, Ilmu
Penyakit Dalam, Jilid III, Edisi 5. Jakarta: Penerbit FK UI; 2009.

5. Brachmachari G. Bio-Flavonoids With Promising Antidiabetic Potentials: A Critical Survey, Opportunity, Challenge and Scope of Natural Products in Medicinal Chemistry. 2011.

6. Lakhanpal P. Quercetin: A Versatile Flavonoid. J. Med. Update 2007; 2(2):2237.

7. Bakova Z. Kolesarova A. Bioflavonoid Quercetin-Food Sources, Bioavailability, Absorbtion and Effect on Animal Cells. J. Microbiol. Biotechn \& Food Sci 2012; 2 (2): 426-33.

8. Duppala, V., Dash RP, Jivrajani MN, Thakur,2 Nirav M. Ravat SK, and Nivsarka M. Simultaneous Quantification of Glibenclamide, Simvastatin, and Quercetin by Using LC-UV Method and Its Application to Pharmacokinetic Study in Rats. Hindawi Publishing Corporation Chromatography Research International. 2013.

9. Soegondo S. Farmakoterapi Pada Pengendalian Glikemia Diabetes Melitus Tipe 2. Dalam : Sudoyo A. W., dkk, editor, Ilmu Penyakit Dalam, Jilid III, Edisi 5. Jakarta: Penerbit FK UI; 2009.

10. Abdelmoaty MA, Ibrahim MA, Ahmed NS, Abdelaziz MA. Confirmatory Studies On The Antioxydant And Antidiabetic Effect Of Quercetin In Rats. Indian J. Clin. Biochem 2010; 25(2): 188-92.

11. Jadhav R, Puchchakayala G. Hypoglicemic and Antidiabetic Activity Of Flavonoids: Boswellic Acid, Ellagic Acid, Quercetin, Rutin On Streptozotocin-Nicotinamide Induced Type 2 Diabetic Rats. Int. J. Pharm Pharmaceut Sci 2012; 2(2):251-6.

12. Pereira DF, Cazarolli LH, Lavado C, Mengatto V, Figueiredo MS, Guedes A, Pizzolatti MG, Silva FR. Effects Of Flavonoids On $\alpha$-Glucosidase Activity: Potencial Targets Of Glucose Homeostatis. Nutrition 2011; 27:1161-7. 